\title{
Financial Literacy, Risk Tolerance, and Financial Management of Micro-enterprises Actors
}

\author{
Heni Hirawati * (D), Yacobo P Sijabat (D), and Axel Giovanni \\ Department of Management, Faculty of Economics, Universitas Tidar, \\ 56116, Magelang, Central Java Province, Indonesia \\ *Corresponding Author: heni.hirawati@untidar.ac.id
}

\section{ARTICLE INFO}

\section{Publication Info:}

Research Article

How to cite:

Hirawati, H., Sijabat, Y. P., $\mathcal{E}$

Giovanni, A. (2021). Financial

Literacy, Risk Tolerance, and

Financial Management of Micro-

enterprises Actors. Society, 9(1),

174-186.

DOI: 10.33019/society.v9i1.277

Copyright $\odot$ 2021. Owned by Author(s), published by Society

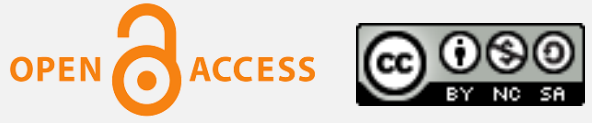

This is an open-access article.

License: Attribution-

NonCommercial-ShareAlike

(CC BY-NC-SA)

Received: January 13, 2021;

Accepted: June 30, 2021;

Published: June 30, 2021;

\begin{abstract}
Micro-enterprises have a significant role in the country's economy. However, business owners must face various problems to develop their business. One of the problems is the limited funding for micro-enterprises due to the low financial literacy of business owners. In addition, the business owner's tolerance for risk is also expected to affect the financial management of micro-enterprises. This study aims to determine the level of financial literacy and tolerance of business owners and the financial management of microenterprises. This research method uses a questionnaire distributed to micro-enterprise owners in Central Java Province and Yogyakarta Special Region. The results showed that the level of financial literacy of micro-enterprise owners was in the medium category. Micro-enterprise owners have a neutral attitude towards risk and are not individuals who dare to take risks but do not avoid risk. Financial management carried out by business owners is still in the poor category. Improvement of financial literacy, understanding of risks, and financial management of micro-enterprises still need to be done.
\end{abstract}

Keywords: Financial Literacy; Financial Management; Micro-enterprises; MSMEs; Risk Tolerance

Copyright (C 2021. Owned by Author(s), published by Society. This is an open-access article under the CC-BY-NC-SA license. 


\section{Introduction}

Micro Enterprises are businesses with the highest share in Indonesia. According to the 2018 report on the development of Micro, Small and Medium Enterprises (MSMEs) and Large Enterprises data by the Ministry of Cooperatives and Small and Medium Enterprises (Kemenkopukm, 2018), 64,199,057 units out of a total of 64,199,606 units of MSMEs and Large Enterprises are micro-enterprises or $99.99 \%$. Absorption of labor also occurs in many microenterprises, which is $97 \%$. The GDP contribution of micro-enterprises is also the highest among other businesses. Based on these data, micro-enterprises have a significant contribution to the economy in Indonesia. The considerable role of micro-enterprises and small and medium enterprises is applied in Indonesia and other countries (Naidu \& Chand, 2012; Katyal \& Xaviour, 2015; Mostapha, 2016; Agyei, 2018; Mor et al., 2020). Tambunan (2019) stated that MSMEs have a significant role for several reasons. For example, MSMEs develop in rural areas and improve the economy in rural areas, absorb labor, and develop business and entrepreneurial skills and a source of business opportunities for women.

The significant role of micro-enterprises for the economy needs to be supported by efforts to increase the ability of business owners to run their businesses. The government has implemented several policies in developing micro-enterprises context, including the issuance of several regulations in the last two decades, significantly to facilitate MSMEs in the marketing and procurement of raw materials. In addition, the government also provides funding assistance for MSMEs by launching a public credit guarantee scheme without collateral, known as People's Business Credit (Tambunan, 2019). The government also issued a policy through the Bank Indonesia Regulation (Bank Indonesia, 2015a), which required commercial banks to provide credit or financing for MSMEs. The amount of MSME credit or funding is set at a minimum of $20 \%$ (twenty percent) calculated based on the ratio of MSME Credit or Financing to total credit or financing.

Although the role of micro-enterprises is enormous for the country's economy, microenterprises still experience obstacles and obstacles in running their business. These constraints can come from internal or external. In general, MSMEs experience constraints on capital, human resources, law, and accountability (Bank Indonesia, 2015b). Capital constraints experienced are limited capital and access to financing. Bank Indonesia noted that $60 \%$ to $70 \%$ of MSMEs do not have access to banking financing. Limited access to financing can be caused by the low financial literacy of MSME owners (Susan, 2020). One of these financial literacy relates to the knowledge of micro business owners about banking. Micro-enterprise owners with limited knowledge about banking do not know the procedures and mechanisms for obtaining loans from banks. Another limitation of micro-enterprises that causes limited capital and access to finance is financial skills, namely financial administration and management systems that have not been appropriately implemented. This causes the bank or financial institution to find it difficult to know assets and operating income. The low level of financial literacy also causes financial records to be kept simple. Even micro-enterprises do not do financial records even though financial records are needed to apply for loans to financial institutions.

Micro-enterprises also face various risks in running their business. According to Alifiana \& Susanti (2018), the risks faced by MSMEs include capital risk, production risk, and marketing risk. Meanwhile, Sajjad et al. (2020) stated that the risks faced by micro-enterprises are financial risk, product risk, market risk, and operational risk. These various risks must be a concern for MSME actors. Understanding the risks faced is important for MSME owners to make the right decisions according to their preferences for risk and properly carry out risk management.

Copyright (C 2021. Owned by Author(s), published by Society. This is an open-access article under the CC-BY-NC-SA license. 
Financial management is also still a problem for micro-enterprises. One of the problems that exist in micro-enterprises is that business actors do not separate personal assets from company assets. Humaira \& Sagoro (2018) state that the various problems experienced by MSME actors reflect the poor financial knowledge and financial attitudes of MSME actors, which will affect financial management behavior. Good financial management needs to be supported by financial knowledge and understanding of the risks of MSME owners. Based on this background, this study aims to determine the level of financial literacy and risk tolerance of micro-enterprise owners and the financial management carried out by micro-enterprise owners.

\section{Literature Review}

\subsection{Micro-enterprise}

According to Law No. 20 of 2008 (Republik Indonesia, 2008), micro-enterprises are productive businesses owned by individuals and/or individual business entities that meet the criteria for micro-enterprises as stipulated in the law. The criteria in question are having a net worth of at most Rp50,000,000.00 (fifty million rupiahs) excluding land and buildings for business premises; or have annual sales of a maximum of Rp300,000,000.00 (three hundred million rupiahs).

Most micro-enterprises in Indonesia are individual businesses which are family businesses. Bank Indonesia (2015b) noted the special characteristics of micro-enterprises, namely (1) types of goods/commodities are not always fixed; may change at any time, (2) the place of business is not always permanent; can change places at any time, (3) have not carried out even simple financial administration, (4) do not separate family finances from business finances, (5) human resources (entrepreneurs) do not yet have a good entrepreneurial spirit, (6) education level the average is relatively very low, (7) in general they do not have access to banking, but some have access to non-bank financial institutions, and (8) generally do not have a business license or other legal requirements including a Taxpayer Identification Number.

\subsection{Financial Literacy}

According to Putra et al. (2016), financial literacy is closely related to financial management individually or personally, including investment decisions, funding, and good asset management. Based on the above understanding, the financial literacy of MSME owners will be related to the decisions of MSME owners in investing their funds, where the sources of funds are obtained, and how MSME owners manage their assets. Anggraeni (2015) examined the effect of the financial literacy level of business owners on the financial management of MSMEs in Depok. The results showed that the level of financial literacy of MSME owners in Depok was still low, so that it affected the ability to manage finances that were not yet good. Aribawa (2016) states that there is an influence of financial literacy on the performance and sustainability of creative MSME businesses in Central Java. This implies that with good financial literacy, it is hoped that MSMEs will be able to make appropriate management and financial decisions to improve performance and business sustainability. In their research, Putra et al. (2016) found that only experienced regret had a significant positive effect on investment decision making. Still, risk tolerance and financial literacy had no impact on investment decisions. Aribawa (2016) states that MSMEs with good financial literacy will achieve their company goals, have a business development orientation, and survive in difficult economic conditions.

There are differences in research results related to demographic factors that affect financial literacy. Yusnita \& Abdi (2018), in their research, found that the literacy level of the microenterprises they studied was still low. The results showed that income level had a significant

Copyright ( $(2021$. Owned by Author(s), published by Society. This is an open-access article under the CC-BY-NC-SA license. https://doi.org/10.33019/society.v9i1.277 
effect on financial literacy, while age, education level, and length of business did not have a significant effect. Rahmayanti (2017) states that age has a significant influence on financial literacy.

\subsection{Risk Tolerance}

Risk is the uncertainty of the results that will be obtained in the future and can cause losses. In financial management, the calculation of operating income is also accompanied by a calculation of risk. The higher the income earned, the higher the risk that must be faced. MSME owners also face various risks for the business they run. A person's attitude towards risk will vary, depending on his preference for risk. According to Sudana (2015), a person's courage to take risks is divided into 3, as follows:

1) Risk seeker, which is a personal attitude that dares to take risks

2) Indifferent to risk, which is a person who does not care about risk, and

3) Risk averter, which is a personal attitude that avoids the risk

Research on risk tolerance has been carried out, including Sunarjanto \& Roida (2013) stated that MSME owners might have different perceptions of risk and have less in-depth knowledge of business risks and financial risks. From the description of respondents, it is known that MSME owners are optimistic about the economic situation, which concludes that respondents like high business risk, but the perception of financial risk is not high. Kannadhasan (2015) examined the financial risk tolerance of investors in India based on six demographic factors, namely age, marital status, education, occupation, and income. Of the six factors studied, only 4 had a significant effect on risk tolerance. Hvide \& Panos (2014) conducted a study to test the theory that states that individuals with high-risk tolerance tend to become entrepreneurs but have poor performance. The results show that $50 \%$ of stock investors start a business, and the businesses have lower sales and ROA.

\subsection{Financial Management}

Financial management is management that involves planning, analyzing, and controlling financial activities. According to Risnaningsih (2017), financial management is one of the problems that is often overlooked by micro-enterprise actors, especially concerning the application of correct financial and accounting management principles. Previous research related to financial management includes Humaira \& Sagoro (2018), which states a positive influence between financial knowledge on financial management behavior in SMEs in the Batik Craft Center, Bantul Regency. The research of Saputra et al. (2018) shows that the competence of human resources and the attitude of love for money have a significant effect on the financial management of SMEs based on the concept of economic entities.

\section{Research Methodology}

The method used is survey research, a research method to a set of objects but only takes part of the population within a certain period by using a questionnaire. The method of collecting data through a questionnaire contains logically related statements to the formulation of the problem. Each statement is an answer that has meaning to determine financial literacy, risk tolerance, and financial management of MSMEs.

Sources of data used in this study are primary data sources obtained directly by the respondents through questionnaires either face-to-face or online. The object of this research is the owner and manager of a business with a micro-scale business located in the provinces of Central Java and Yogyakarta. The sample used in this study was 75 micro-enterprises in the 
area of Central Java and Yogyakarta. The sample selection was based on the ease of obtaining research data due to the limitations of the research conditions and time.

The questionnaire questions in this study are a modification of Anggraeni (2015), which refers to the 2013 Developing Indonesian Financial Literacy Index. Questionnaire questions are divided into five indicators, namely:

1) Measurement of general banking knowledge

2) Basic financial literacy

3) Measurement of knowledge about risk

4) Owner's tolerance for risk

5) Owner's skills in managing finances

\section{Results and Discussion}

\subsection{Characteristics of Respondents}

The research data was obtained from distributing questionnaires to 75 respondents who are owners or managers of micro-enterprises in the Province of Central Java and the Special Region of Yogyakarta. From the questionnaire data, the characteristics of the respondents were obtained as follows:

Table 1. Characteristics of Respondents

\begin{tabular}{|c|c|c|c|}
\hline Characteristics & Description & $\begin{array}{l}\text { Number of } \\
\text { Respondents }\end{array}$ & Percentage \\
\hline Gender & $\begin{array}{l}\text { Male } \\
\text { Female }\end{array}$ & $\begin{array}{l}28 \\
47\end{array}$ & $\begin{array}{l}37 \% \\
63 \%\end{array}$ \\
\hline Age & $\begin{array}{l}\leq 25 \text { years old } \\
>25 \leq 40 \text { years old } \\
>40 \leq 55 \text { years old } \\
\geq 55 \text { years old }\end{array}$ & $\begin{array}{c}12 \\
32 \\
26 \\
5\end{array}$ & $\begin{array}{c}16 \% \\
43 \% \\
35 \% \\
6 \% \\
\end{array}$ \\
\hline Last Education & $\begin{array}{l}\text { Primary School } \\
\text { Junior High School } \\
\text { Senior High School } \\
\text { Diploma } \\
\text { Bachelor }\end{array}$ & $\begin{array}{c}4 \\
15 \\
35 \\
5 \\
16\end{array}$ & $\begin{array}{c}5 \% \\
20 \% \\
47 \% \\
7 \% \\
21 \% \\
\end{array}$ \\
\hline Type of Business & $\begin{array}{l}\text { Trading } \\
\text { Industry } \\
\text { Service } \\
\text { Other business }\end{array}$ & $\begin{array}{c}29 \\
30 \\
11 \\
5\end{array}$ & $\begin{array}{c}39 \% \\
40 \% \\
15 \% \\
6 \%\end{array}$ \\
\hline Length of Business & $\begin{array}{l}1 \text { year } \\
>1 \leq 3 \text { years } \\
>3 \leq 5 \text { years } \\
>5 \leq 10 \text { years } \\
>10 \text { years }\end{array}$ & $\begin{array}{c}9 \\
19 \\
12 \\
17 \\
18\end{array}$ & $\begin{array}{l}12 \% \\
25 \% \\
16 \% \\
23 \% \\
24 \%\end{array}$ \\
\hline Number of Employees & $\begin{array}{l}1 \text { - } 4 \text { employees } \\
5 \text { - } 19 \text { employees }\end{array}$ & $\begin{array}{c}67 \\
8\end{array}$ & $\begin{array}{l}89 \% \\
11 \%\end{array}$ \\
\hline
\end{tabular}

Research respondents are dominated by women as much as $63 \%$. This confirms the theory put forward by Tambunan (2019) that micro-enterprises are a place for women to do business.

Copyright (C 2021. Owned by Author(s), published by Society. This is an open-access article under the CC-BY-NC-SA license. 
The majority age is 25 years to 40 years, a productive period, and the last education of most respondents in high school, which is as much as $47 \%$. As many as $24 \%$ of businesses have been in existence for more than ten years, with $89 \%$ of respondents having one to four employees. Because the business scale is still very small, the business can only employ an average of 1 to 4 people.

\subsection{Financial Literacy}

The level of financial literacy of micro business owners was obtained from respondents' answers to 10 questions. Financial literacy is calculated by dividing the number of respondents' correct answers by the total number of questions then multiplied by one hundred percent. Respondents' answers were then divided into three categories: group 1 with a value of $<60 \%$, which means the business owner has low knowledge. Group 2 is with a value of $60 \%-80 \%$, which means that the business owner has moderate financial knowledge and group 3 is with a value of $>80 \%$, which indicates that the business owner has high knowledge.

Based on respondents' answers to questions related to financial literacy, the following is the result of the percentage of correct answers that are distinguished by gender, age, education, and length of business.

Table 2. Financial Literacy Level Based on Demographics

\begin{tabular}{|l|l|c|}
\hline \multicolumn{1}{|c}{ Characteristics } & \multicolumn{1}{|c|}{ Description } & $\begin{array}{c}\text { Percentage of Correct } \\
\text { Response }\end{array}$ \\
\hline \multirow{3}{*}{ Gender } & Male & $78 \%$ \\
& Female & $78 \%$ \\
\hline \multirow{5}{*}{ Age } & $\leq 25$ years old & $73 \%$ \\
& $>25 \leq 40$ years old & $79 \%$ \\
& $>40 \leq 55$ years old & $78 \%$ \\
& $\geq 55$ years old & $76 \%$ \\
\hline \multirow{5}{*}{ Last Education } & Primary School & $63 \%$ \\
& Junior High School & $73 \%$ \\
& Senior High School & $75 \%$ \\
& Diploma & $92 \%$ \\
& Bachelor & $87 \%$ \\
\hline \multirow{5}{*}{ Length of Business } & 1 year & $78 \%$ \\
& $>1 \leq 3$ years & $80 \%$ \\
& $>3 \leq 5$ years & $83 \%$ \\
& $>5 \leq 10$ years & $72 \%$ \\
& $>10$ years & $77 \%$ \\
\hline
\end{tabular}

From Table 2, males and females have the same literacy level. Financial literacy is not influenced by gender. Then from the age factor, the difference in literacy levels is also not that big, and there is no visible influence of age on the financial literacy level. The education factor influences the level of financial literacy. The higher the level of education, the higher the level of financial literacy. As for the length of business, there is not much difference in the literacy level in long-established business and new business. A long-established business does not guarantee that business owners have a higher literacy level. 
Based on the categorization, the level of financial literacy, the number, and percentage of respondents, in general, can be seen in Table 3 as follows:

Table 3. Business Owner's Financial Literacy Level

\begin{tabular}{|c|c|c|}
\hline Category & Number of Respondents & Percentage \\
\hline Low (<60\%) & 2 & $2.7 \%$ \\
\hline Medium $(\mathbf{6 0} \% \mathbf{- 8 0} \%)$ & 49 & $65.3 \%$ \\
\hline High $(\mathbf{8 0} \%)$ & 24 & $32 \%$ \\
\hline
\end{tabular}

From the results of primary data processing contained in Table 3, it can be seen that only two business actors or $2.7 \%$ are in a low category, $65.3 \%$ are in a medium category, and $32 \%$ of business actors have a high level of literacy. In more detail, the average level of financial literacy of micro-enterprise owners can be seen in Table 4 below:

Table 4. Respondents Financial Literacy for Each Question

\begin{tabular}{|c|c|c|c|}
\hline \multirow[b]{2}{*}{ Questions } & \multicolumn{3}{|c|}{ Financial Literacy Level } \\
\hline & $\begin{array}{c}\text { Low } \\
(<60 \%)\end{array}$ & $\begin{array}{l}\text { Medium } \\
(60 \%-80 \%)\end{array}$ & $\begin{array}{c}\text { High } \\
(>80 \%)\end{array}$ \\
\hline 1. Identity when opening a bank account & & & 98 \\
\hline $\begin{array}{l}\text { 2. The minimum amount of funds when opening } \\
\text { a bank account }\end{array}$ & & & 98 \\
\hline 3. Minimum balance in a bank account & & & 93 \\
\hline 4. Bank products & 44 & & \\
\hline $\begin{array}{l}\text { 5. Savings account guaranteed by the } \\
\text { government }\end{array}$ & & 72 & \\
\hline 6. Simple Interest & & 67 & \\
\hline 7. Inflation & & & 92 \\
\hline 8. Investment & & 63 & \\
\hline 9. Profit calculation & & & 97 \\
\hline 10. Money Illusion & 52 & & \\
\hline Average & \multicolumn{3}{|c|}{77} \\
\hline
\end{tabular}

Table 4 shows the percentage of respondents who answered each question correctly and the average number of correct answers to financial literacy questions. In the table, what will be seen is the correct response or correct answer for each survey question. This description aims to find out which items the respondent has a good understanding of and which do not.

Based on Table 4, the average financial knowledge of business owners is $77 \%$, where the literacy level is included in the medium category. The highest value is in identity knowledge when opening a bank account and knowledge of the minimum amount of funds when opening a bank account with a value of $98 \%$. Meanwhile, the question with the lowest score is the question regarding bank products. This indicates that respondents already understand the mechanism for opening bank accounts but are not very familiar with the products offered by banks and do not know which bank products provide the highest income. 
From the table, it can be concluded that micro-enterprise owners have good financial literacy. This shows that the government's efforts to improve financial literacy are quite successful.

\subsection{Risk Tolerance}

Before being asked questions about risk tolerance, respondents were also asked questions about risk knowledge to determine the level of literacy of business owners towards risk. Risk knowledge of business owners based on demographics can be seen in the following table:

Table 5. Financial Literacy Level Based on Demographics

\begin{tabular}{|l|l|c|}
\hline \multicolumn{1}{|c|}{ Characteristics } & \multicolumn{1}{|c|}{ Description } & Percentage of Correct \\
Response
\end{tabular}

From Table 5, we can see that men have a higher risk knowledge of $75 \%$. Respondents aged 25 to 40 years had the highest risk knowledge compared to other ages. Then the education factor and length of business can not be seen the influence of these two factors on the knowledge of the business owner's risk.

The tolerance of micro business owners is obtained from the respondents' answers to 5 questions. The form of the question is a Likert scale question with five categories from strongly disagree to agree with the statement submitted strongly. The literacy level is based on the average score obtained, with a score of 1 being the lowest score and 5 being the highest score. We can see the risk tolerance of business owners in Table 6 below: 
Table 6. Financial Literacy Level Based on Demographics

\begin{tabular}{|l|l|c|}
\hline \multicolumn{1}{|c|}{ Characteristics } & \multicolumn{1}{|c|}{ Description } & Average \\
\hline \multirow{4}{*}{ Agender } & Male & 2.9 \\
& Female & 2.5 \\
\hline \multirow{5}{*}{ Last Education } & $\leq 25$ years old & 2.9 \\
& $>25 \leq 40$ years old & 2.8 \\
& $>40 \leq 55$ years old & 2.4 \\
& $\geq 55$ years old & 2.9 \\
\hline \multirow{5}{*}{ Length of Business } & Primary School & 2.5 \\
& Junior High School & 2.6 \\
& Senior High School & 2.7 \\
& Diploma & 2.6 \\
& Bachelor & 2.7 \\
\hline & 1 year & 2.7 \\
\hline & $>1 \leq 3$ years & 2.9 \\
\hline & $>3 \leq 5$ years & 2.5 \\
\hline & $>5 \leq 10$ years & 2.7 \\
\hline
\end{tabular}

Based on Table 6, men have a higher risk tolerance than women. Meanwhile, age, education, and length of business do not affect the business owner's risk tolerance. There was no significant difference in the risk tolerance of the three factors. The average risk tolerance of business owners is 2.6. This indicates that business owners are risk-neutral. Business owners do not avoid risk but also do not feel challenged by risk.

\subsection{Financial Management}

This variable also uses questions with a Likert scale with five categories consisting of never, rarely, sometimes, often, and always, which states the frequency of implementation of each activity in the question. From the answers of each respondent then the average is calculated and interpreted based on Table 7 as follows:

Table 7. Scale Category

\begin{tabular}{|cc|}
\hline Scale & Category \\
\hline $1-1.80$ & Very poor \\
\hline $1.81-2.60$ & Poor \\
\hline $2.61-3.40$ & Below Average \\
\hline $3.41-4.20$ & Good \\
\hline $4.21-5.00$ & Very good \\
\hline
\end{tabular}

The results of research related to the financial management of micro-enterprise owners can be seen in Table 8 as follows: 
Table 8. Micro-enterprise Financial Management

\begin{tabular}{|c|c|c|c|c|c|c|c|}
\hline \multirow{2}{*}{ Questions } & \multicolumn{5}{|c|}{ Scale } & \multirow{2}{*}{ Average } & \multirow{2}{*}{ Category } \\
\hline & 1 & 2 & 3 & 4 & 5 & & \\
\hline Make financial planning & 6 & 7 & 18 & 15 & 29 & 3.7 & Good \\
\hline $\begin{array}{l}\text { Additional business funds } \\
\text { through loan credit }\end{array}$ & 23 & 6 & 29 & 9 & 8 & 2.6 & Poor \\
\hline Create a sales budget & 12 & 6 & 15 & 17 & 25 & 3.5 & Good \\
\hline Make a budget & 13 & 9 & 9 & 21 & 23 & 3.4 & Below-average \\
\hline Make a cash budget & 16 & 4 & 18 & 14 & 23 & 3.3 & Below-average \\
\hline Recording cash receipts & 10 & 12 & 18 & 14 & 21 & 3.3 & Below-average \\
\hline $\begin{array}{l}\text { Separating personal assets from } \\
\text { business finances }\end{array}$ & 3 & 8 & 24 & 15 & 25 & 3.7 & Good \\
\hline Make a record of profit and loss & 16 & 10 & 17 & 15 & 17 & 3.1 & Below-average \\
\hline $\begin{array}{l}\text { Prepare financial reports in the } \\
\text { form of a "balance sheet" }\end{array}$ & 28 & 10 & 18 & 10 & 9 & 2.5 & Poor \\
\hline $\begin{array}{l}\text { Monitoring and evaluation of } \\
\text { business finances }\end{array}$ & 3 & 15 & 18 & 18 & 21 & 3.5 & Good \\
\hline
\end{tabular}

From Table 8 above, it is known that the financial management of micro-enterprises is still in the poor category. Good financial management is in the form of financial planning, sales budget, separation of assets, and monitoring \& evaluation. Business actors still rarely use additional business funds through credit. Business owners tend to use internal funds rather than external funds. This could be due to business owners' lack of financial literacy in lending capital to financial institutions. In addition, the recording of financial statements that are rarely carried out is the preparation of a balance sheet. This could also be due to the limited knowledge of business actors in terms of preparing balance sheets. Financial management by business owners also rarely makes budgets and records income statements.

\section{Conclusion}

The average level of financial literacy of micro business owners in Central Java Province and Yogyakarta Special Region is $77 \%$, where the literacy level is included in the medium category. In this regard, the government's efforts to improve public financial literacy still need to be continued and improved. On risk tolerance, micro-enterprise owners have a neutral attitude towards risk. Micro-enterprise owners are not individuals who dare to take risks but also do not avoid the risks. This risk tolerance attitude is related to decision-making by business owners. The courage to take risks is carried out to increase the income obtained, following the risk and return trade-off, namely, the higher the risk faced, the higher the return to be obtained. However, the micro-enterprise owners here tend to be more cautious. In managing business finances, two things become the main concern because they are in the below-average category: financing from external sources and financial records in a balance sheet form. Micro-enterprise owners rarely do these two things. This is an indication that the financial literacy of business owners is still not good. In general, the average financial management of micro-enterprises is still in the poor category. Therefore, it is necessary to increase the ability of micro-enterprise actors in terms of the financial management of MSMEs. Poor financial management is due to the lack of knowledge of business actors, so it is necessary to conduct training that will increase the insight and skills of business actors in financial management. 


\section{Acknowledgment}

The authors would like to thank the Directorate of Research and Community Service, Directorate General of Strengthening for Research and Development, for this research's financial support. Likewise, the authors would like to thank the Institute for Research and Community Service of Universitas Tidar and all respondents who participated during this research.

\section{Declaration of Conflicting Interests}

The authors have declared no potential conflicts of interest concerning the study, authorship, and/or publication of this article.

\section{References}

Agyei, S. K. (2018). Culture, financial literacy, and SME performance in Ghana. Cogent Economics and Finance, 6(1), 1-16. https:// doi.org/10.1080/23322039.2018.1463813

Alifiana, M. A., \& Susanti, N. (2018). Analisis Potensi Risiko Umkm Di Kabupaten Kudus. Media Ekonomi, 18(2), 71-81. Retrieved from http://jurnalnasional.ump.ac.id/index.php/MEDEK/article/view/3052

Anggraeni, B. D. (2015). Pengaruh Tingkat Literasi Keuangan Pemilik Usaha Terhadap Pengelolaan Keuangan. Studi Kasus: UMKM Depok. Jurnal Vokasi Indonesia, 3(2), 109_ 121. http://dx.doi.org/10.7454/jvi.v3i1.23

Aribawa, D. (2016). Pengaruh Literasi Keuangan Terhadap Kinerja dan Keberlangsungan UMKM di Jawa Tengah. Siasat Bisnis, 20(1), 1-13. https://doi.org/10.1007/s10006-0130431-4

Bank Indonesia. (2015a). Pemberian Kredit atau Pembiayaan Oleh Bank Umum dan Bantuan Teknis Dalam Rangka Pengembangan Usaha Mikro, Kecil, dan Menengah. 1-13. Retrieved from http://www.bi.go.id/id/peraturan/ssk/Documents/pbi_171215.pdf

Bank Indonesia. (2015b). Profil Bisnis Usaha Mikro, Kecil Dan Menengah (UMKM). Bank Indonesia dan LPPI, 1-135.

Kemenkopukm. (2018). Perkembangan Data Usaha Mikro, Kecil, Menengah Dan Usaha Besar. Retrieved from https://www.kemenkopukm.go.id/uploads/laporan/1580223129_PERKEMBANGAN DATA USAHA MIKRO, KECIL, MENENGAH (UMKM) DAN USAHA BESAR (UB) TAHUN 2017 - 2018.pdf

Humaira, I., \& Sagoro, E. M. (2018). Pengaruh pengetahuan keuangan, sikap keuangan, dan kepribadian terhadap perilaku manajemen keuangan pada pelaku UMKM sentra kerajinan batik KABUPATEN BANTUL. Nominal: Barometer Riset Akuntansi dan Manajemen, 7(1), 96-110. https://doi.org/10.21831/nominal.v7i1.19363

Hvide, H. K., \& Panos, G. A. (2014). Risk tolerance and entrepreneurship. Journal of Financial Economics, 111(1), 200-223. https://doi.org/10.1016/j.jfineco.2013.06.001

Kannadhasan, M. (2015). Retail investors' financial risk tolerance and their risk-taking behaviour: The role of demographics as differentiating and classifying factors. IIMB Management Review, 27(3), 175-184. https:// doi.org/10.1016/j.iimb.2015.06.004

Katyal, A., \& Xaviour, B. (2015). A study on MSMEs'-role in propelling economic development of India \& a discussion on current HR issues in MSMEs' in India. International Journal of Scientific and Research Publications, 5(2), 1-11. Retrieved from http://www.ijsrp.org/research-paper-0215.php?rp=P383745 
Mor, S., Madan, S., Archer, G. R., \& Ashta, A. (2020). Survival of the Smallest: A Study of Microenterprises in Haryana, India. Millennial Asia, 11(1), 54-78. https://doi.org/10.1177/0976399619900609

Mostapha, N. F. (2016). Financing of Small and Medium-Sized Enterprises (SMEs) in Developing Countries. The 2016 WEI International Academic Conference Proceedings, 169177. Boston, USA. Retrieved from https://www.westeastinstitute.com/wpcontent/uploads/2016/09/Nehale-F.-Mostapha.pdf

Naidu, S., \& Chand, A. (2012). A comparative study of the financial problems faced by micro, small and medium enterprises in the manufacturing sector of Fiji and Tonga. International Journal of Emerging Markets, 7(3), 245-262. https:// doi.org/10.1108/17468801211236974

Putra, I. P. S., Ananingtiyas, H., Sari, D. R., Dewi, A. S., \& Silvy, M. (2016). Experienced Regret, dan Risk Tolerance pada Pemilihan Jenis Investasi. Journal of Business and Banking, 5(2), 271-282. https://doi.org/10.14414/jbb.v5i2.548

Rahmayanti, D. (2017). Pengaruh Karakteristik Demografi Terhadap Literasi Keuangan Masyarakat Kota Bengkulu. MOTIVASI: Jurnal Manajemen dan Bisnis Universitas Muhamadiyah Palembang, 2(2), 311-331. https://doi.org/https://doi.org/10.32502/motivasi.v2i2.2048

Risnaningsih, R. (2017). Pengelolaan Keuangan Usaha Mikro Dengan Economic Entity Concept. Jurnal Analisa Akuntansi Dan Perpajakan, 1(1), 41-50. https://doi.org/10.25139/jaap.v1i1.97

Sajjad, M. B. A., Kalista, S. D., Zidan, M., \& Christian, J. (2020). Analisis Manajemen Risiko Bisnis (Studi Pada Cuanki Asoy Jember). Jurnal Akuntansi Universitas Jember, 18(1), 51-61. Retrieved from https://jurnal.unej.ac.id/index.php/JAUJ/article/view/18123

Saputra, K. A., Ekajayanti, L. G. P. S., \& Anggiriawan, P. B. (2018). Kompetensi Sumber Daya Manusia dan Sikap Love of Money dalam Pengelolaan Keuangan Usaha Mikro Kecil Menengah (UMKM). Jurnal Reviu Akuntansi dan Keuangan, 8(2), 135-146.

Sudana, I. M. (2015). Manajemen Keuangan Perusahaan Teori dan Praktik. Jakarta, Indonesia: Erlangga.

Sunarjanto, A. N., \& Roida, Y. H. (2013). Menterjemahkan Toleransi Risiko Pemilik UMKM melalui Keputusan Penggunaan Modal yang Mengandung Risiko Bisnis dan Risiko Keuangan. Prosiding Seminar Nasional dan Call for Paper Forum Manajemen Indonesia (FMI) Ke-5. Pontianak, Kalimantan Barat.

Susan, M. (2020). Financial literacy and growth of micro, small, and medium enterprises in west java, indonesia. International Symposia in Economic Theory and Econometrics, 27, 39-48. https://doi.org/10.1108/S1571-038620200000027004

Tambunan, T. (2019). Recent evidence of the development of micro, small and medium enterprises in Indonesia. Journal of Global Entrepreneurship Research, 9(1). https://doi.org/10.1186/s40497-018-0140-4

Republik Indonesia. (2008). Undang-Undang Nomor 20 Tahun 2008 tentang Usaha Mikro, Kecil, dan Menengah. Lembaran Negara Republik Indonesia Tahun 2008 Nomor 93. Jakarta, Indonesia.

Yusnita, R. Ri., \& Abdi, M. (2018). Pengaruh Faktor Demografi Terhadap Literasi Keuangan. Journal of Economic, Business and Accounting, 2(1), 163-184. https:// doi.org/10.1227/01.NEU.0000349921.14519.2A 
About the Authors

1. Heni Hirawati obtained her Master's degree in Management from Universitas Islam Indonesia in 2015. The author is an Assistant Professor at the Department of Management, Faculty of Economics, Universitas Tidar, Indonesia.

E-Mail: heni.hirawati@untidar.ac.id

2. Yacobo P Sijabat obtained his Master's degree in Management from Universitas Gadjah Mada, Indonesia, in 2017. The author is an Assistant Professor at the Department of Management, Faculty of Economics, Universitas Tidar, Indonesia.

E-Mail: yacobo.djabat@untidar.ac.id

3. Axel Giovanni obtained his Master's degree in Management from Universitas Diponegoro, Indonesia, in 2018. The author is an Assistant Professor at the Department of Management, Faculty of Economics, Universitas Tidar, Indonesia.

E-Mail: axelgiovanni@untidar.ac.id 